\title{
Dynamics of Forest Disturbance in Central Part of the Šmava Mountains between 1985 and 2007 Based on Landsat TM/ETM+ Satellite Data
}

\author{
MARTIN HAIS ${ }^{1}$, JAKUB LANGHAMMER ${ }^{2}$, PAVLA JIRSOVÁ ${ }^{3}$, LUBOMÍR DVOŘÁK ${ }^{3}$ \\ ${ }^{1}$ University of South Bohemia, Faculty of Sciences, Department of Ecosystem Biology \\ ${ }^{2}$ Charles University in Prague, Faculty of Science, Department of Physical Geography \\ and Geoecology \\ ${ }^{3}$ Šmava National Park, Department of Informatics and GIS
}

\begin{abstract}
During the last more than twenty years, various types of forest disturbance (i.e. insect outbreak, clearcutting) occurred in the central part of the Šumava Mountains. The bark beetle (Ips typographus [L.]) outbreak in this region resulted in regional-scale spruce forest decay. Clear-cutting was done here to prevent further bark-beetle propagation in the buffer zones.

Dynamics of the disturbance types has been analyzed by processing 15 satellite Landsat TM/ETM+ scenes from the years 1985, 1987, 1989, 1990, 1992, 1994, 1995, 1996, 1998, 1999, 2002, 2003, 2004, 2006 and 2007. Supervised classification (Maximum Likelihood) was used to identify deforested areas. Classification proved that main forest disturbance in the Central Šumava Mountains occurred between 1995 and 1998, when the dispersion of the spruce bark beetle in forest stands accelerated. Total area of decayed spruce forests due to bark beetle during the whole period was estimated at $1763 \mathrm{ha}$, out of it 1013 ha in the Bavarian Forest NP, 749 ha in the Šmava NP. Total clear-cut areas reached more than 387 ha in the Šumava NP, whereas they only reached a total of 13 ha in the Bavarian Forest NP. Compared to published data, the results for both disturbance types are lower as they did not include the area to the east of the peak Luzný. The final disturbance model shows progress and dynamics of spruce bark beetle spreading in both national parks as well as the development of forest losses due to clear-cutting mainly in the Sumava NP.
\end{abstract}

Key words: change detection - Landsat - forest disturbance

\section{Introduction}

Disturbances play an important role in landscape changes. In general, disturbance can be defined as a physical force, a process or event that causes a sudden deviation in system behavior or a change in system properties (Rykiel et al., 1988). Rykiel et al. (1988) state the basic classification of disturbances and their characteristics. In terms of forest stands, Waring \& Running (1998) define disturbance as any factor causing a significant reduction of the leaf area index (LAI) during a period exceeding one year. Reduction in leaf area, or defoliation, results from the impact of a number of factors (insect, pathogenic fungi, atmospheric deposition, etc.); a special group is represented by forest cutting or clearing, where all or a majority of the cut-down woods are removed. In terms of natural forest regeneration, disturbance can be defined as a process of tree die-off, during which natural forest regeneration starts (Oliver \& Larson, 1996). 
The bark beetle (Ips typographus [L.]) outbreak in this region resulted in regionalscale spruce forest decay. Clear-cutting was done here to prevent further bark-beetle propagation in the buffer zones and, last but not least, also windbreaks of forest stands played a role.

The years 1983 and 1984 can be held as origins of the calamitous outbreak of spruce bark beetle in the Sumava Mountains, caused by windbreak of forest stands 173 ha in the Bavarian Forest National Park in Germany (Heurich et al., 2001; Skuhravý, 2002). At that time the Bavarian Forest NP management decided not to process fallen trees on the area of 88 ha and leave further development to natural processes without human interferention. Unprocessed lying logs provided conditions for development of the spruce bark beetle that afterwards, in 1986, attacked also live trees (Skuhravý, 2002). Spreading reached its largest development to the northwest of Luzný in the direction to Velký Špičník and Malý Špičník, and from there further to the north, northeast and east.

The bark beetle accelerated the spruce forest decay in 1995, the year in which the area of spruce forests decayed in the Bavarian Forest NP during one year exceeded 200 ha for the first time, and the total loss amounted to 367 ha. In the following year, 1996, the yearly loss more than doubled ( $827 \mathrm{ha}$ ). In that year, the highest forest loss in the Bavarian Forest NP for the period 1988-2000 occurred. During 1997-2000 yearly losses in forest stands caused by the bark beetle were within the interval of 400-600 ha. Only 55 ha of newly decayed spruce forests were found out by processing 2001 aerial photos (Heurich et al., 2001, Heurich \& Martin, 2002).

On Czech side, aerial photos from 1992 showed apparent individual attacked trees and in 12 cases also larger patches (15-20 trees) within the area between Špičník, Blatný Vrch, in the direction to Roklan (Skuhravý, 2002). Spruce bark beetle spreading followed, manifested especially by occurrence of focuses and by dispersal within the involved stands.

The Šumava National Park management declared and extended (in 1995 and 1997, respectively) a non-intervention zone to the south of the road connecting Roklanská Lodge and Březník, with a total area of 1450 ha. The maximum infestation was reached in 1996, when it spread to $80 \%$ of the total area. Outside of the zone, the Sumava NP management took measures consisting in wood substance reclamation intended at stopping the spruce bark beetle's further advancement. $10 \%$ of the reclaimed trees were debarked and left on spot. Since 1996, the clear-cuts have been extensively reforested, and on top of spruce, also other admixed tree species have been planted there: rowan, beech, fir and sycamore. Zatloukal et al. (2001) mention the importance of additional planting of admixed tree species in clear-cuts in order to bring the following forest generation closer to natural conditions. Table 1 shows overall consequences of the bark beetle calamity until 2002.

Forest revitalization includes natural regeneration in decayed spruce forests as well as artificial planting of tree species in the Bavarian Forest and Šumava NP intervention zones. The comparison carried out by Jonášová and Prach (2004) for the Šumava NP implies that the development in the number of seedlings (natural rejuvenation) is higher in decayed spruce forests rather than in clear-cuts. Besides, a heterogeneous age structure of regenerating stands develops in decayed spruce stands. 
Table 1: Spruce forest loses in the central part of Sumava Mts. until 2000

\begin{tabular}{|l|c|c|c|}
\hline National Park & Decayed forest (ha) & Clear cut areas (ha) & Loses in mil. $\mathrm{m}^{3}$ \\
\hline NP Bayerischer Wald & 3650 & 270 & $1.5-1.7$ \\
\hline NP Šumava & 1450 & 1150 & $1.1-1.3$ \\
\hline Total & 5100 & 1420 & $2.6-3.0$ \\
\hline
\end{tabular}

Source: Skuhravý 2002

Successful forest regeneration in decayed spruce forests were confirmed by a study in the Bavarian Forest NP (Jehl, 2005).

This paper mainly aims at testing the potential of satellite data with medium spatial resolution (Landsat TM/ETM+) for identification of disturbed areas and it further aims at comparing the results with the aerial photographs digitalization method.

\section{Locality}

The area of interest is the central part of Šmava Mountains (see Fig. 1), and the main focus lies in forest stand disturbances: 1) spruce forests (Picea abies [L.] Karst.) decayed due to the outbreak of the spruce bark beetle (Ips typographus L.), which peaked at the turn from the $20^{\text {th }}$ to the $21^{\text {st }}$ century; 2) clear-cuttings, which were created as a defence against further bark beetle spreading.

\section{Area of Interest

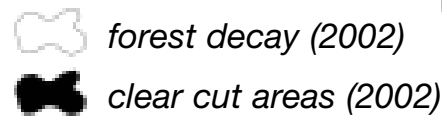

NP Bayerischer Wald
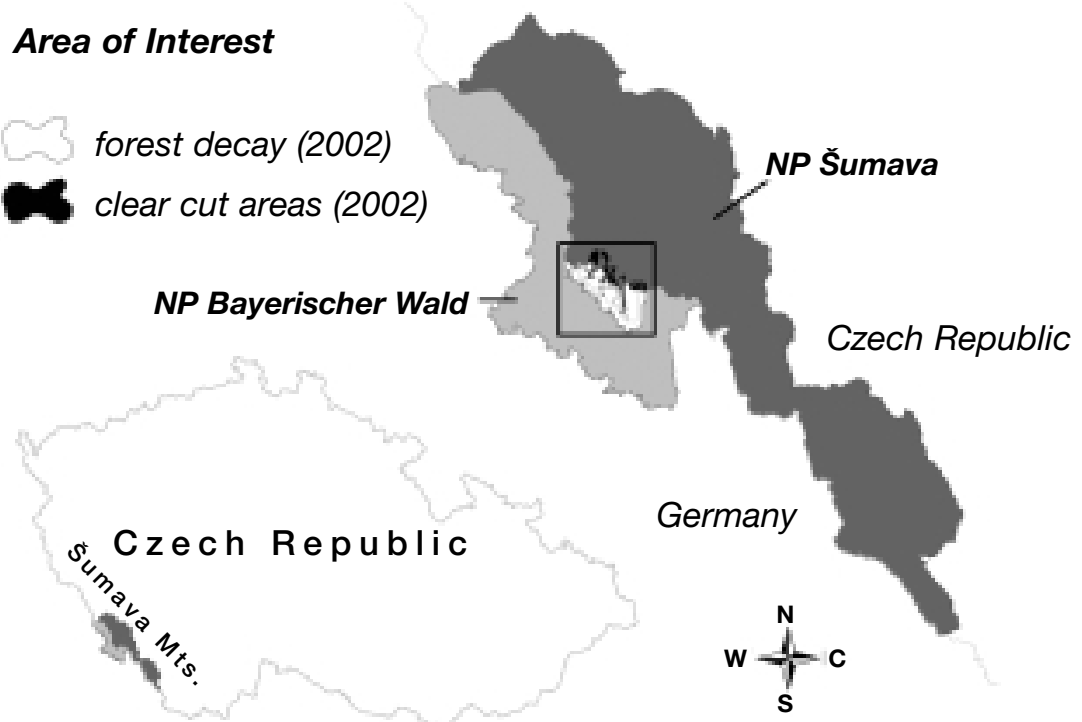

Figure 1: Study area located in the Šmava Mountains, Czech Republic-Germany border region 
The site stretches into two national parks: Šumava (Czech Republic) and Bavarian Forest (Germany). On Czech side, the territory is delineated by the connecting line Medvědí Hora - Modravská Hora, and further towards Březník and through Mokrůvky in the direction to Luzný; on German side, it approximately includes the areas between the peaks Luzný and Roklan. The average elevation varies between 1100-1200 m a.s.l. The whole territory shows high yearly precipitation values; besides, Březník is held for the rainiest place in the Šumava Mountains with its yearly precipitation reaching up to $1552 \mathrm{~m}$ (Strnad, 2003).

\section{Methods}

For the purpose of this study, 13 satellite Landsat TM/ETM+ sceneries were used, which were taken from June to November (see Table 2). Reason for this heterogeneity in the months of data acquisition is frequent cloud formation in Šmava Mountains, which significantly decreases the number of useful scenes in a given year.

Table 2: Landsat TM and ETM+ imagery

\begin{tabular}{|l|c|c|}
\hline Acquisition date & Landsat scene & Landsat sensor \\
\hline Nov. 26, 1985 & Path 192, Row 26 & TM \\
\hline Jul. 11, 1987 & Path 192, Row 26 & TM \\
\hline Sep. 18, 1989 & Path 192, Row 26 & TM \\
\hline Nov. 23, 1990 & Path 192, Row 26 & TM \\
\hline Sep. 19, 1992 & Path 192, Row 26 & TM \\
\hline Jul. 11, 1995 & Path 191, Row 26 & TM \\
\hline Jun. 1, 1996 & Path 192, Row 26 & TM \\
\hline Nov. 8, 1998 & Path 192, Row 26 & TM \\
\hline Jul. 28, 2002 & Path 192, Row 26 & ETM+ \\
\hline Aug. 8, 2003 & Path 192, Row 26 & TM \\
\hline Aug. 10, 2004 & Path 192, Row 26 & TM \\
\hline Jul. 15, 2006 & Path 192, Row 26 & TM \\
\hline Jun. 25, 2007 & Path 191, Row 26 & TM \\
\hline
\end{tabular}

First, satellite data were atmosphericaly corrected (e.g. high amount of cloud of low thickness) using ATCOR module (Geomatica 10, 2005). Next, geometric corrections were carried out, i.e. rectification of satellite data into the S-JTSK coordinate system according to CR Satellite Map (2002 ArcData Praha, s.r.o.). Supervised classification (Maximum Likelihood) was used to delineate deforested areas (Geomatica 10, 2005).

Result of the classification was compared with the data based on visual interpretation of aerial orthophotos in three time horizons (1995, 1996 and 1998). The visual interpretation was carried out for only a part of the Šumava NP, and it concerned only spruce forests decayed due to bark beetle. Similarity rate of both data sets was compared by calculation of Kappa and Cramer V coefficients (Cramér, 1999). 


\section{Results}

Detection of forest disturbance areas was based on the assumption that clear-cuts and decayed forest stands will have a different spectral response compared to other

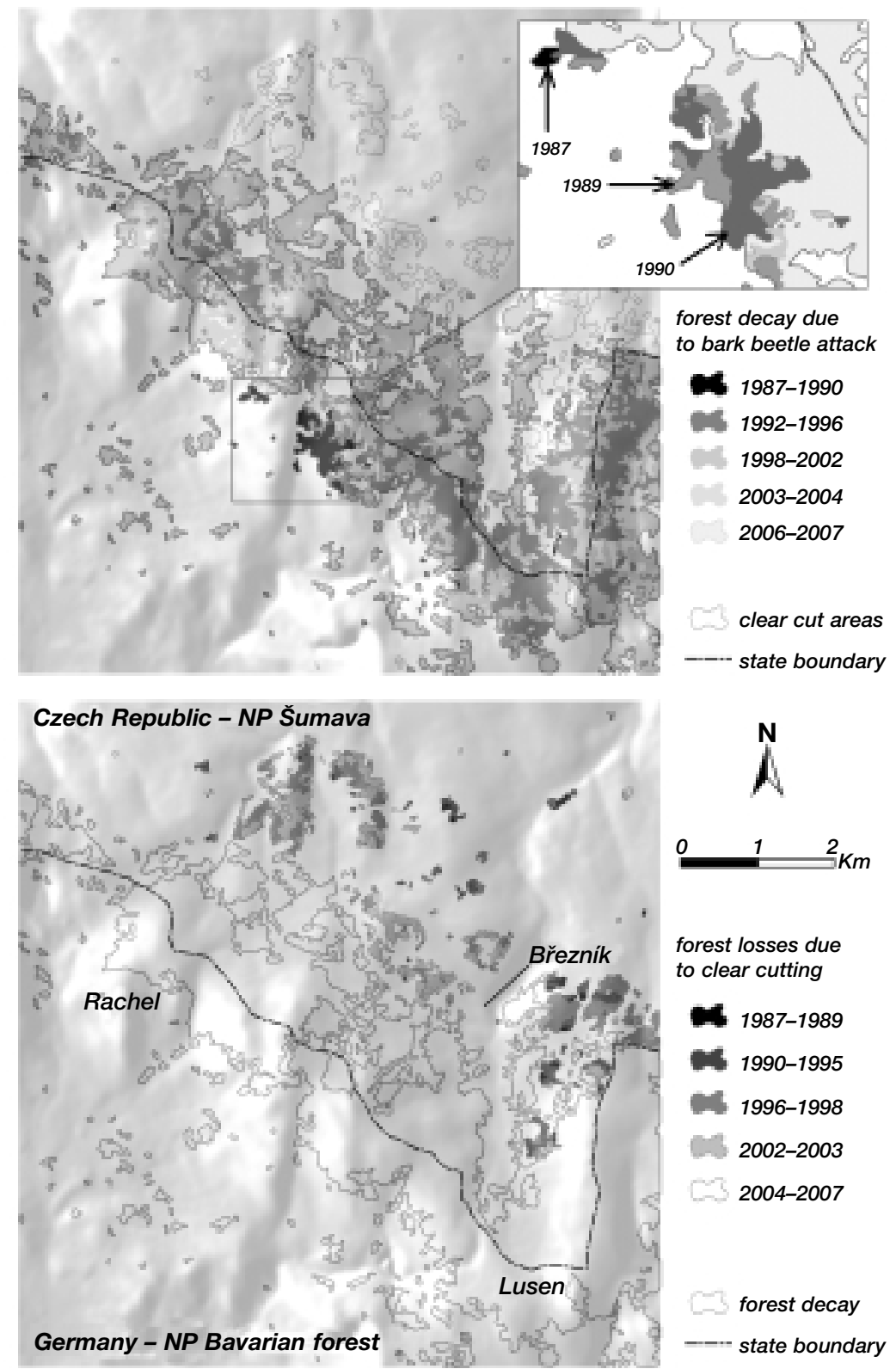

Figure 2: The development of two types of forest disturbance (forest decay, clear-cutting) 
landcover units. On the other hand, it is important to take into account that, within the succession process, the herbaceous layer will regenerate in time, and, thus, the spectral manifestation will become more difficult to detect (Healey et al., 2007). That is why the classified areas were always added to the deforested areas from previous years. The beginning of spruce stands decay due to bark beetle is localized in the German part of the Šmava Mountains, where one central focus was detected in 1987, from which the bark beetle continued to spread (see Fig. 2). Areas infested in subsequent years are always located not far away from areas infested the year before. The main direction of bark beetle spreading is northwest; another regularity to be mentioned is attacking forest stands located especially in Šumava hilltop regions. Figure 2 also shows development of clear-cuts disturbance. Clear-cuts originated in two main stages: 1) in the early 1990s clear-cuts were created on western hillsides of Velká Mokrůvka and Malá Mokrůvka; 2) after 1995 interventions started to be used especially on the north edge of the non-intervention zone. The borderline between the intervention and nonintervention zones runs along the road between Březník and Roklanská Lodge. Figures 3 and 4 show the dynamics of both disturbance types. With respect to different management of both national parks, disturbed area values are stated for both Šumava parts separately. In terms of spruce stand decay, there was a sharp rise in infested areas after 1996, and a decrease again after 2002; the infested area peaked in 1998 in both national parks. Nevertheless, the forest losses due to spruce bark beetle infestation are higher in the Bavarian Forest NP in total as well as in individual years.

In terms of clear-cuts, the situation is completely different as they were used within intervention management in the Šumava NP in a significantly higher extent.

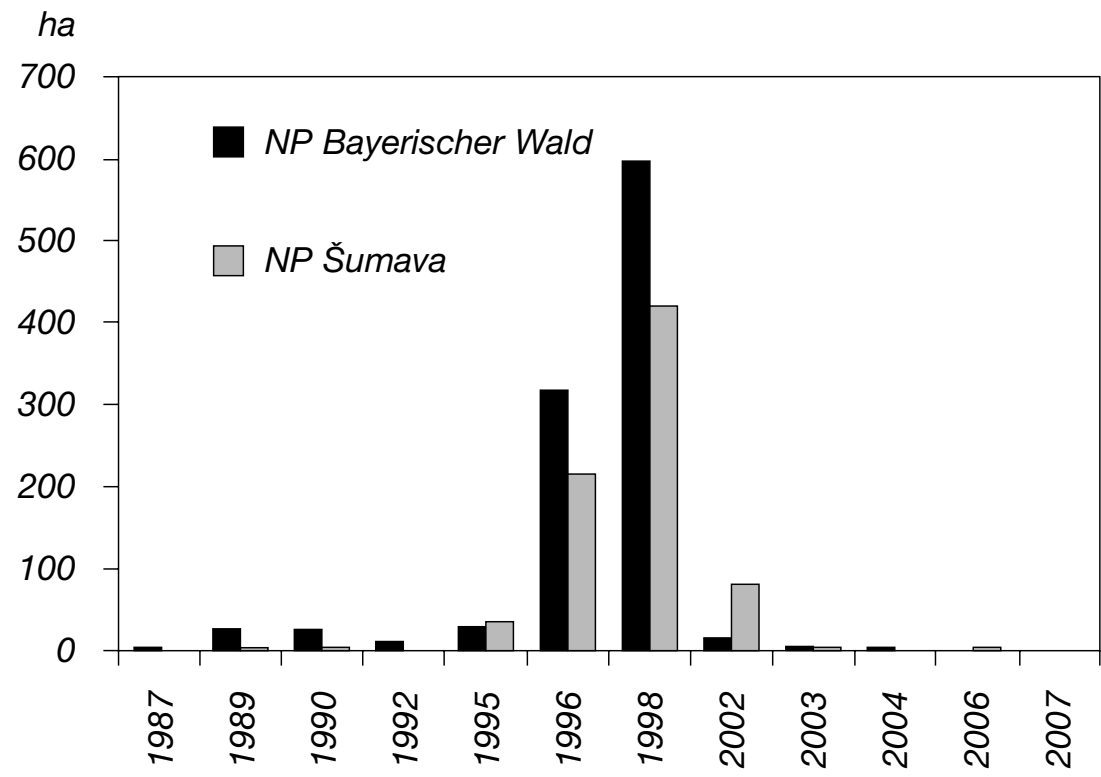

Figure 3: Dynamic of spruce forest decay due to bark beetle outbreak in the central part of Sumava Mountains 
Reclamation works on the Czech side peaked in 1998 and 2002 when the area of newly created clear-cuts made out more than 100 ha each year. Resulting areas of identified clear-cuts during the whole period in question represent more than 400 ha and 13 ha in the Šumava NP and in the Bavarian Forest NP, respectively.

Classification accuracy was evaluated based on Cramer V and Kappa coefficients (see Table 3). The resulting classification accuracy varies and shows a rising trend from 1995 to 1998.

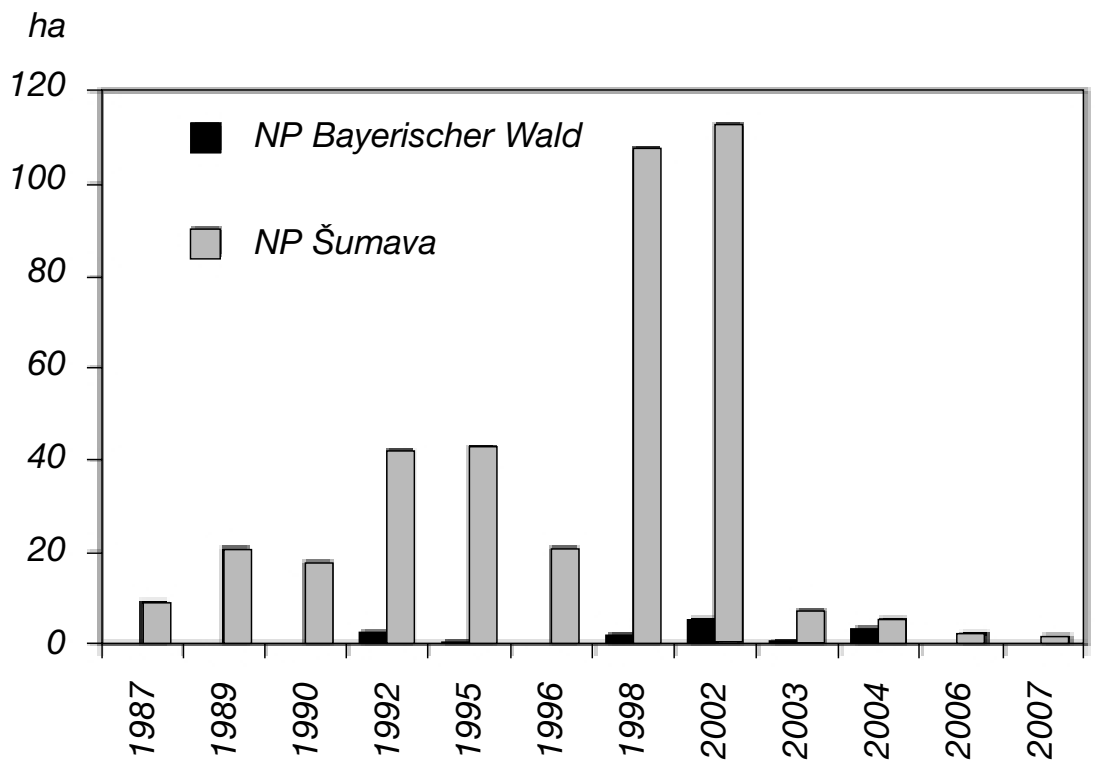

Figure 4: Spruce forest loses due to clear-cutting in the central part of Šmava Mountains

Table 3: The comparison of the decayed forest detected using the areal and satellite data

\begin{tabular}{|l|l|l|l|}
\hline Year & $\mathbf{1 9 9 5}$ & $\mathbf{1 9 9 6}$ & $\mathbf{1 9 9 8}$ \\
\hline Cramer V & 0.28 & 0.58 & 0.77 \\
\hline Kappa & 0.23 & 0.56 & 0.75 \\
\hline
\end{tabular}

\section{Discussion and conclusions}

Forest stand disturbances represent a significant landscape change, which depending on its area and type - may have a number of consequences: 1) impact on hydrological regime, matter losses, and erosion (Uunila et al., 2006); 2) impact on local climate (Geiger, 1965; Petrík a kol., 1986); 3) impact on carbon cycle (Houghton, 1993); and, last but not least, also 4) change in landscape character (Löw \& Míchal, 2003). Therefore, it is important to determine not just the extent of such changes, but also the dynamics of their development. 
On one hand, multitemporal analysis of forest stand disturbance is important in order to understand the regularities of such phenomena; on the other hand, the outcomes can be used to generate models, what mainly applies to models of forest stand decay due to insect outbreaks.

The forest decay delineation using classification of Landsat scenes confirms results published by Wermelinger et al. (2004) stating that during one year, new bark beetle patches are not established at an average distance higher than $200 \mathrm{~m}$ from the original infestation patch. In individual years, the resulting frontal propagation of spruce forest decay therefore creates well identifiable zones.

Although the years 1983 and 1984 are considered to be beginning of bark beetle outbreak in the Šumava Mountains (Heurich et al., 2001; Skuhravý, 2002), in this study, the spruce forest decay was only identified on the 1987 satellite scenery, and not on the 1985 one, which was available. In our opinion, it can be explained by the fact that, according to Skuhravý (2002), the bark beetle had been spreading only within local windbreaks until 1986. Only after that year, it started to attack live trees on larger areas of the German side, which enabled their identification.

Dynamics of spruce forest decay, manifested especially by acceleration of bark beetle spreading between 1996 and 1998, has been described for both the Šumava NP (Skuhravý, 2002) and the Bavarian Forest NP (Heurich et al., 2001). However, the resulting areas of decayed stands are underestimated compared to the data published. For example, 532 ha of decayed spruce forests were classified up for the Bavarian Forest NP for 1996, whereas Heurich et al. (2001) states 827 ha. There are two reasons for such underestimation, which was also found out while comparing data on the Sumava NP. The main reason is that the studied area does not include a part to the east from Luzný and Velké Mokrůvky and Malé Mokrůvky. It might be further caused by the resolution limitation of the Landsat TM/ETM+ satellite $(30 \mathrm{~m})$, because of which the pixels bearing mixed radiometric information (mixels) are not included in classification outcomes (Lillesand et al., 2004). This reason is indirectly confirmed also by growing Kappa and Cramer V coefficients while comparing classified satellite data and aerial photos data for 1995, 1996 and 1998. The lowest Kappa and Cramer $\mathrm{V}$ coefficient values in 1995 result from the fact that in the given year, there was a high proportion of infested stands in the form of individual patches comprising of several trees on Czech side (Skuhravý, 2002). Such patches could be identified on aerial photos, but not on satellite data with lower spatial resolution. In the following year, 1996, a high proportion of patches joint into larger areas due to a massive bark beetle outbreak, and the trend continued in 1998 as well. At that time, the spruce stand decay in the Central Šumava Mountains was of large-scale nature (hundreds of ha), and, thus, there was a closer correspondence between the aerial photos and the satellite data, which also found a manifestation in the highest Kappa value (0.75).

As for classification of clear-cuts, we assumed that the herbaceous layer would get damaged or destroyed during felling and removal of the trees, and it would be thus possible to spectrally differentiate between those areas and montane meadows. For the most part, the assumption proved to be correct, but the areas might have been underestimated if the forest stand was felled in a year, for which there were no satellite scenes available (e.g. 1997), and fast regeneration of herbaceous layer could have 
caused that the following year, such areas were not possible to differentiate from montane meadows and, thus, could remain partially unclassified.

We can conclude that the satellite data classification method is a suitable tool for identification of forest disturbances, mainly in regional scale. The accuracy of forest disturbance detection using Landsat data depends mainly on the spectral response of this areas and/or on the pattern (size of patches, connectivity etc.). For more detailed study the use of very high spatial resolution data (e.g. Quickbird) is more suitable.

\section{Acknowledgements}

The presented research was funded by the Joint Research Scheme MSM 0021620831 "Geographical Systems and Risk Processes in Context of Global Changes and European Integration" and by the research project VaV SM/2/57/05 "Long-term changes in fluvial ecosystems in floodplains affected by extreme floods" which is fully appreciated by the authors.

\section{References}

CRAMÉR, H. (1999): Mathematical Methods of Statistics, Princeton University Press.

GEIGER, R. (1965): The climate near the ground. Harvard Univ. Press, Harvard. (pp. 611)

Geomatica 10. (2005): Geomatica 10, Focus user guide. Geomatics Enterprises. Ontario, Canada.

HEALEY, S. P., COHEN, W. B., YANG, Z., KENNEDY, R. E. (2007): Remotely sensed data in the mapping of forest harvest patterns. (pp. 63-84) In: Wulder, M. A., S. E. Franklin, (eds.) Understanding Forest Disturbance and Spatial Pattern: Remote Sensing and GIS Approaches, CRC Press (Taylor and Francis), Boca Raton, FL.

HEURICH, M., REINELT, A., FAHSE, L. (2001): Die Buchdruckermassenvermehrung im Nationalpark Bayerischer Wald. In: Nationalparkverwaltung Bayerischer Wald: Waldentwicklung im Bergwald nach Windwurf und Borkenkäferbefall. (pp. 9-48) Bayerische Staatsforstverwaltung.

HEURICH, M., MARTIN, K. (2002): Luftbildauswertung zur Waldentwicklung im Nationalpark Bayerischer Wald 2001 - Ein neues Verfahren und seine Ergebnisse zur Totholzflächenkartierung. (pp. 1-25). Nationalparkverwaltung Bayerischer Wald.

HOUGHTON, R. A. (1993): Is carbon accumulating in the northern temperate zone? Global Biogeochem Cycles. 7, 611-617.

JEHL, H. (2005): Naturwälder im Nationalpark Bayerischer Wald und deren ungestörte Waldentwicklung. Přirozené lesy v NP Bavorský les a jejich nerušený vývoj. In: Hubený (Ed.) Přírodě blízké lesnictví na bázi přírodních procesů - cesta $\mathrm{k}$ udržitelným lesům. Naturnahe Forstwirtschft auf Basis der natürlichen Processe - ein Weg zu nachhaltigen Wäldern. Semináŕ 16.-17. 6. 2005.

JONÁŠOVÁ, M., PRACH, K. (2004): Central-European mountain spruce (Picea abies (L.) Karst.) forests: regeneration of tree species after a bark beetle outbreak. Ecological Engineering, 23, 15-27.

LILLESAND, T. M., KIEFER, R. W., CHIPMAN, J. W. (2004): Remote Sensing and Image Interpretation. John Wiley and Sons. New York.

LÖW, J., MÍCHAL, I. (2003): Krajinný ráz. Lesnická práce. Kostelec nad Černými lesy.

OLIVER, C. D., LARSON, B. C. (1996): Forest Stand Dynamics. John Wiley \& Sons, New York.

PETRÍK, M., HAVLÍČEK, V., UHRECKÝ, I. (1986): Lesnícka bioklimatológia. Príroda. Bratislava.

RYKIEL, E. J., JR., COULSON, R. N., SHARPE, P. J. H., ALLEN, T. F. H., FLAMM, R. O. (1988): Disturbance propagation by bark beetles as an episodic landscape phenomenon. Landscape ecology, 3, 129-139.

SKUHRAVÝ, V. (2002): Lýkožrout smrkový (Ips typographus L.) a jeho kalamity. Der Buchdrucker und seine Kalamitäten. Agrospoj, Praha.

SOKAL, R. R., ROHLF, F. J. (1998): Biometry: the principles and practice of statistics in biological research. W. H. Freeman and Company, New York.

STRNAD, E. (2003): Podnebí Šumavy. In: Šumava, př́roda, historie, život. Nakladatelství Miloš Uhlî̌r - Baset. 
UUNILA, L., GUY, B., PIKE, R. (2006): Hydrologic effect of Mountain Pine Beetle in the Interior Pine Forests of British Columbia: Key questions and current knowledge. Streamline, Watershed Management Bulletin. 9 (2), 1-7.

WARING, R. H., RUNNING, S. W. (1998): Forest ecosystems: analysis at multiple scales. New York, NY: Academic Press.

ZATLOUKAL, V., KADERA, J., ČERNÁ, J., PŘílEPKOVÁ, S. (2001): Předběžné vyhodnocení stavu a vývoje přirozené obnovy v NP Šumava v prostoru Mokrůvka - Špičník - Březnická hájenka. Aktuality šumavského výzkumu. 110-115.

\section{Résumé}

V centrální oblasti Šumavy došlo za posledních více než dvacet let k významnému odlesnění. To se týká zejména rozpadu smrkových porostů v důsledku kalamitního přemnožení Lýkožrouta smrkového (Ips typographus L.), které se projevilo jak na německé (NP Bavorský les), tak české straně (NP Šumava). Na území NP Šumava došlo zejména $\mathrm{v}$ druhé polovině 90 . let $\mathrm{k}$ aktivním zásahům proti dalšímu šîření Lýkožrouta prostřednictvím asanace smrčin, jejímž výsledkem je pásmo holých sečí. Posledním typem odlesnění jsou polomy v důsledku orkánu Kyrill. Dynamika vývoje zmíněných typů odlesnění byla hodnocena zpracováním družicových 15 scén Landsat TM/ETM+ z let: 1985, 1987, 1989, 1990, 1992, 1994, 1995, 1996, 1998, 1999, 2002, 2003, 2004, 2006 a 2007. Na družicových datech byly provedeny geometrické a radiometrické korekce. Pro identifikaci odlesněných ploch byla využita ř́zená klasifikace typu Maximum Likelihood. Výsledky klasifikace ukazují, že k hlavnímu odlesnění centrální Šumavy došlo mezi roky 1995 a 1998, kdy došlo k akceleraci rozšíření lýkožrouta smrkového v lesních porostech. Plochy rozpadlých smrčin vlivem lýkožrouta za celé sledované období byly určeny na 1763 ha, přičemž na NP bavorský les připadá 1013 ha a na NP Šumava 749 ha. Odlesnění v důsledku aktivních zásahů proti šiření lýkožrouta se uplatňovalo zejména v NP Šumava po roce 1995. Celkové plochy holých sečí v NP Šumava dosáhly více než 387 ha, zatímco v NP Bavorský les pouze 13 ha. Výsledky obou typů odlesnění jsou oproti údajům z literatury nižší, nebot hodnocené území nezahrnuje oblast na východ od vrcholu Luzného. Výsledný model odlesnění ukazuje postup a dynamiku šiření lýkožrouta v obou národních parcích a vývoj sanace lesních porostů zejména v NP Šumava.

RNDr. Martin Hais, Ph.D.

University of South Bohemia

Faculty of Sciences Studentská 13

37005 České Budějovice Czech Republic

e-mail:martin.hais@seznam.cz. phone: +420387772310

RNDr. Jakub Langhammer, Ph.D.

Charles University in Prague

Fakulty of Science

Albertov 6

12200 Prague 2

Czech Republic

e-mail:langhamr@natur.cuni.cz phone: +420221951364

Ing. Lubomír Dvořák, Ph.D., a Ing. Pavla Jirsová, Ph.D.

Šmava National Park

1. máje 260

38501 Vimperk

Czech Republic

e-mail: lubomirdvorak@npsumava.cz pavla.jirsova@npsumava.cz phone: +420388450828 